\title{
Dividend policy, energy utilities and the investment megacycle
}

\author{
Paul Simshauser and Angela Catt* \\ AGL Energy Ltd \\ Level 6, 144 Edward Street \\ Brisbane, QLD, Australia, 4001.

\begin{abstract}
Few decisions made by firms receive more consistent annual attention by Board Directors than dividend policy. For 60 years, financial economists have focused on deriving an optimal dividend policy. Research tells us dividends should be sticky to suit the firm's clientele and any franking credits should be distributed as fast as possible given their time value. An industry maturity cycle exists, which reinforces lower dividends during expansionary phases and raising dividends when growth prospects moderate. Energy utilities have been through a decade-long harvest period, but are now re-entering an above-trend investment growth phase. Utility dividend policies therefore require careful review.
\end{abstract}

Keywords: Dividend Policy, Electric Utilities. JEL Codes: D61, L94, L11 and Q40.

\section{Introduction}

Few decisions by firms receive more continuous annual attention from Board Directors than dividend policy. Despite this, interaction between researchers and practitioners is remarkably limited. This article is focused on the dividend policy of energy utilities. In Australia for example, merchant utilities currently target dividend payout ratios of about $60 \%$ of earnings, while regulated utility ratios are closer to $80 \%$. Almost 60 years of financial economic research is yet to formally identify dividend policy optimality. That a spectrum of dividend policies exists, ranging from low to high payout ratios, provides the obvious evidence. Nonetheless, we believe a set of guiding parameters exists given the asset stock, taxation system, industry structure and investment outlook facing energy utilities. We identify above trend-growth capital investment for the 2010s following a virtual investment blackout in Australia during the 1990s - a trend not unfamiliar to many European and US Utilities. In many respects, the structural correction to capital allocation in Australia resembles 'an investment megacycle'. Network investment commenced the cycle from 2007, driven by rapidly rising peak demand and asset replacement, while carbon-related policies are driving anticipated investment in merchant generating equipment at a rate and pace not previously witnessed at any time in the industry's history. The long-range cyclical nature of investment in the energy sector, aging power system infrastructure and carbon-related policy shocks, means that a review of dividend policy is appropriate.

This article is set out as follows; in Section 2, we provide an overview of investment by energy utilities. In Section 3, we undertake an expansive review of the literature on dividends starting with the foundation works of Lintner (1956) and Miller and Modigliani (1961), running through to more contemporary works from Australia and the US. Section 4 reviews quantitative research on the inverse correlation between industry growth and the cost of capital, and dividend payout ratios. In Section 5, we analyse the dividend policies of Australian energy utilities over the period 2002-2009 and examine forecast growth requirements of the power industry. Section 6 reviews relevant global energy utility payout ratios. Our concluding remarks on dividend policy follow.

\footnotetext{
* Paul Simshauser is Chief Economist at AGL Energy Ltd and Professor of Finance at Griffith University. Angela Catt is Manager Strategy \& Planning at AGL Energy Ltd. The authors are grateful for the peer review of this article by Professor Stephen Gray from the University of Queensland and JP Morgan Director of Equity Capital Markets, David Gray. Any errors or omissions remain entirely the responsibility of the authors.
} 


\section{The investment megacycle in the electricity industry}

It should be obvious that any increase (decrease) in dividends merely brings forward (delays) the date at which future capital raisings will be required by firms, holding investment plans constant. This is because the source and use of funds must ultimately balance as equation (1) notes:

$$
\Pi+\Delta \mathrm{S}=\mathrm{I}+\mathrm{D}
$$

Where: $\Pi \quad=$ Cash from operations

$\Delta \mathrm{S} \quad=$ Cash raised from new share issues

I $\quad=$ Investment in Assets

D $\quad=$ Dividends paid

Putting to one side the level of dividends currently paid by energy utilities, it is useful to examine the long history and forecast of capital investment in regions which now form the Australian National Electricity Market (NEM). This is presented in Figure 1, along with average electricity tariffs using the Queensland region as a representative 'electricity tariff marker'.

Figure 1: Historical analysis of investment in generation, transmission and distribution assets

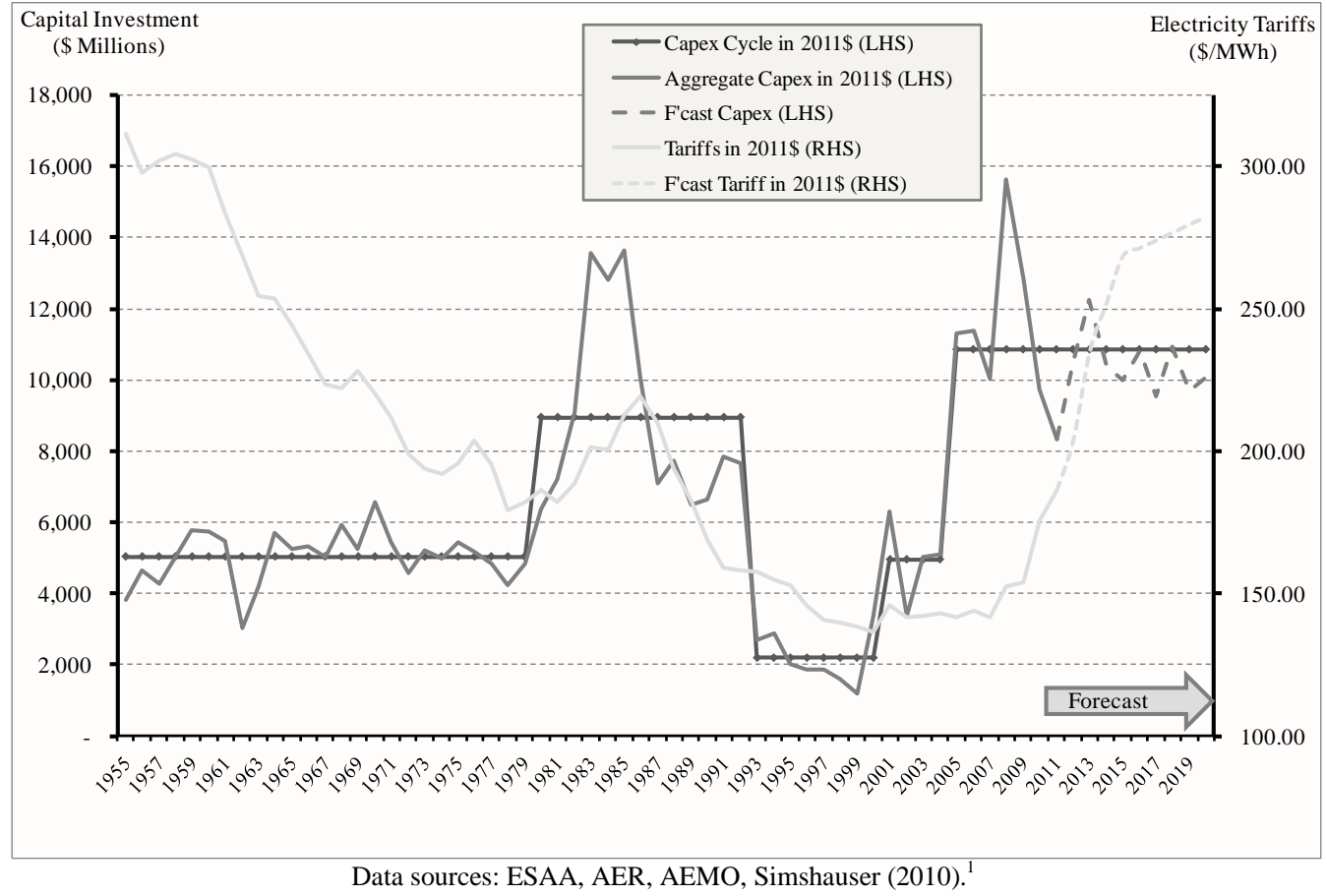

Aggregate annual investment in fixed assets is illustrated in Figure 1 by the solid dark-gray line, along with a superimposed proximate 'industry investment cycle' which has been made possible by converting all capital expenditures into constant 2011 dollars. Investment between 1955 and 1978 was largely stable at about $\$ 5$ billion pa, with load growth throughout the regions that would later form the NEM averaging 7.9\% per annum. In the next period spanning 1979 to 1990, load growth slowed to $5.4 \%$ but industry investment soared to about $\$ 9$ billion pa. This coincided with a period of sharply rising residential demand ${ }^{2}$, and (an expected) sharp increase in industrial loads primarily in metals manufacturing. Kellow (1996) observed that east coast State Governments encouraged electricity investment programs, but in the event less than half of the envisaged industrial loads materialized thus leaving the industry with a chronic structural oversupply of generating and transmission equipment. The period between 1990 and 2000 could be best described as an "investment blackout" with aggregate annual investment falling to just \$2 billion; a period in which prior investments were harvested. The decline in average tariffs, as 
measured on the RHS y-axis, illustrates this outcome. The short period between 2000 to 2006 saw investment revert to trend growth of $\$ 5$ billion, while the start of the investment megacycle is visible from 2007 onwards. This megacycle raises questions regarding dividend policy.

\section{On the theory of dividend policy}

Company dividend policy determines the rate at which annual profits are distributed to stockholders as distinct from that which will be retained for subsequent reinvestment and is a key decision of Board Directors. Dividend policy has been the topic of extensive theoretical and applied research for almost 60 years, generally with a view to identifying an optimal rate (i.e. high payout, low payout or "irrelevance"). The origins of research on dividend policy can be traced back to Lintner (1956) who noted dividend policy was 'an active decision variable' of the firm. In his study, 15 variables $^{3}$ thought to be important to Board Directors in relation dividend decisions were used to screen over 600 listed equities from which 28 were selected for subsequent investigation, representing 196 company years of dividend action with clear guidelines emerging: ${ }^{4}$

- In no instance were dividend payout decisions undertaken without carefully considering the existing rate as an 'optimum problem' by Board Directors;

- Changes to existing dividend policies were only undertaken after Board Directors satisfied themselves that the decision would be viewed positively over the long run;

- Dividend policy exhibits inertia and conservatism because of a deep belief by Board Directors that shareholders prefer stability, with equity markets placing a premium on stability and gradual growth;

- Because of this, Board Directors sought dividend policies that were most unlikely to require reversal within a two-year timeframe. Avoiding erratic changes to dividend policy was achieved by changing dividends with consideration of forecast earnings changes; and

- No other decision made by Board Directors was considered as consistently important (i.e. year-by-year) as dividend policy.

\subsection{Dividend irrelevance}

The first material step in the analysis of optimal dividend policy came from Miller and Modigliani's (1961, p.414) seminal work which demonstrated that in perfect capital markets, dividend policy is irrelevant to the firm's value. Perfect capital markets assume no taxes or market frictions (i.e. transactions costs), no agency costs and symmetric information. Dividend irrelevance arises because, for a given investment plan and holding capital structure constant, funds used to pay dividends could only be replaced from one source; new share issues. Dividend policy is therefore a tradeoff between retaining earnings to finance future investment, or paying dividends and raising new equity to replace payouts:

... Given a firm's investment policy, the dividend payout policy it chooses to follow will affect neither the current price of its shares nor the total return to its shareholders. Like many other propositions in economics, the irrelevance of dividend policy, given investment policy, is "obvious once you think of it". It is merely one more instance of the general principle that there are no "financial illusions" in a rational and perfect economic environment. Values there are determined solely by "real" considerations - in this case the earning power of the firm's assets and its investment policy - not by how the earnings power are "packaged" for distribution...

The Miller and Modigliani (1961) dividend irrelevance proposition is the subject of a formal mathematical proof under the conditions of perfect capital markets. By demonstrating under such 
conditions that dividend policy is actually irrelevant, an enormously important contribution to our understanding of dividend policy was made. Since we know in practice that dividend policy is not irrelevant, by deduction it must relate to those factors that are assumed away by the consideration of perfect capital markets. Thus our analysis of dividends must turn to market imperfections: taxes, transactions costs, agency costs, and asymmetric information.

\subsection{Taxation costs}

Miller and Modigliani (1961, p.431) noted that of all market imperfections, the one "remotely capable of producing a concentration is the substantial advantage accorded to taxation". The expansive literature on dividend policy presents the view that under a classical taxation system such as the US (and Australia until 1987), the presence of taxes tends to favour profit retention where the tax burden of dividends is greater than capital gains tax for (non-pension fund) investors. Under classical taxation systems, dividends paid to individual investors are doubletaxed; once in the hands of the firm via company tax, and once in the hands of shareholders as income tax. Capital gains on the other hand are typically tax free or taxed at lower rates in classical tax systems. Under such systems, it seems intuitively logical that maximizing shareholder wealth would be best achieved by paying no dividend to avoid double taxation, and pursue stock growth given low or zero capital gains tax. As Miller and Scholes (1978, p.333334) noted long ago in the case of the United States,

...in 1976 for example, corporations paid the Treasury $43 \%$ of their earnings of $\$ 111$ billion in corporation income taxes. From the after-tax remainder, they then paid out $\$ 31$ billion in dividends, thereby subjecting a substantial fraction of their stockholders to still another tax bite under the personal income tax. This seemingly masochistic dividend payout policy cannot convincingly be attributed to a dearth in opportunities to reinvest those dividends profitably within the corporate sector... For at the same time that corporations were shovelling $\$ 31$ billion of dividends out the front door, they were raking some $\$ 47$ billion in through the back door in the form of new equity issues, new bond issues and new bank credit...

In Australia, Nicols (1990) observed that prior to dividend imputation rules being introduced in 1987, the top 100 ASX-listed companies averaged a 44\% payout ratio. Ball et al. (1979, p.15) noted that:

...If a tax differential between dividends and capital gains were the only determinant of dividend policy, this argument is said to imply the existence of (a) a large group of companies paying out all earnings as dividends and owned by investors who pay higher taxes on capital gains; (ii) a large group of companies retaining all earnings for capital gains owned by investors who pay high taxes on dividends; and (iii) a third group of companies owned by investors who pay equal taxes on dividends and capital gains, with dividend policies varying between these extremes. The fact that we do not observe this polarization implies either that tax differentials are not an exclusive determinant of dividend policy, or that the argument misrepresents their effects...

This seemingly illogical approach to shareholder wealth, from a taxation perspective, was initially explained by the existence of an 'investor clientele', information costs and agency costs which is discussed next.

\subsection{The 'clientele' effect}

Since taxation affects investor classes differently, it is thought that a 'dividend clientele' effect exists. Miller and Modigliani (1961) noted that one clientele is just as good as another while Black and Scholes (1974) considered 'clienteles' based on a demand and supply equilibrium concepts for the aggregate stock of low and high dividend firms, similarly concluding that once 
equilibrium had been reached, no firm would have any incentive to change dividend policy. Clienteles are thought to be quite coarse, and so only non-trivial changes to dividend yield would shift a company from a low or a high yielding asset class.

An empirical study by Pettit (1977) found a significant dividend clientele effect. High dividend yields had positive correlations with older-aged investors and negative correlations with the taxable income of investors. Investors facing income tax rates higher than capital gains taxes were found to target low dividend yield/high growth stocks, and vice versa. Llewellen et al. (1978) focused on a 'tax-induced clientele' amongst other variables and also concluded that investors are influenced by taxation and an inverse relationship existed between marginal tax rates and dividend yields; but it was of no long-run economic importance to the firm in considering dividend policy. A consistent thematic amongst all clientele research is that while they exist, it is unlikely to impact the long-run value of the firm.

That investor clienteles exist implies that companies should follow a stable dividend policy since a wildly fluctuating dividend policy is unlikely to appeal to any class of investor, given transaction costs of switching stocks. This then raises the concern, in theory at least, of whether a sharp change in dividend policy would lead to an adverse impact through mass clientele exit. Richardson, Sefcik and Thompson (1986) tested whether sharp dividend policy changes lead to marked increases in trading volumes as existing clientele traded-out of their stock. They examined 192 firms announcing their first cash dividend and identified substantial increases in trading volume around announcement dates. However, their analysis concluded that the vast majority of volumes related to the information content of future earnings, and that 'clientele adjustment' was trivial. That is, in the presence of asymmetric information, investors know less about the firm than executive managers do. Investors may then infer something about the future prospects of the firm by observing the dividend policy. The issue here is that even if a very strong clientele exists, a singular, and enduring, switch of dividend policy should not result in a negative stock price reaction if the change was made for sound financial reasons. However, material discounts might emerge if a firm gains a reputation for frequent changes in dividend policy because incoming clientele would need to factor in potential transaction costs of selling earlier than expected under adverse changes.

\subsection{Company tax imputation credits and the preferences of shareholders: clientele}

The research above relates to dividends under classical taxation systems. Under an imputation taxation system such as that introduced in Australia in 1987 (where stockholders receive a tax credit stapled to their dividends for company taxes already paid, thus neutralising the double taxation of dividends), resident shareholder preferences unambiguously shift to higher dividend payout ratios, on average. In short, imputation credits favour franked dividends (i.e. from profits which have been subject to company tax). Because money has a time-value shareholders will prefer to receive tax credits as soon as possible. Thus for an Australian firm, one could conclude, with considerable justification, that an optimal dividend policy is to pay the maximum 'franked dividend' (i.e. from 'taxed profits') possible. Hamson and Ziegler (1990) noted that individuals can make use of tax credits to reduce their personal income taxes (i.e. the imputation effect) and any payment of company dividends now reduces capital gains taxes later (i.e. the CGT effect). This has clearly been the case with corporate Australia; Reserve Bank economists Lowe and Shuetrim (1993) undertook a study of corporate financial structures and dividend policies of 224 Australian firms over the period 1973-1990. They found dividend payout ratios jumped from $47 \%$ to $76 \%$ over the three years after the imputation system was introduced. ${ }^{5}$

When the dividend imputation system was first introduced, company tax and marginal tax rates were identical at $49 \%$ and so shareholders would prefer dividends. But the company tax rate is now $30 \%$, which is different to marginal income tax rates of $45 \%$. Additionally, Superannuation Funds (i.e. Australian Pension Funds) are taxed at 15\%. And to compound matters, capital gains 
taxes are now discounted to $50 \%$ for individuals and $33 \frac{1}{3} \%$ for Super Funds. Howard and Brown (1992) noted that with such diversified tax positions, a Pareto Optimal dividend policy is unlikely to exist. Since dividend policy should be set to attract a certain investor clientele; and since Super Funds are the 'dominant investors', paying the maximum franked dividend seems a logical starting point for utilities (although it is worth noting that it is the marginal investor who sets stock prices, and this may well be non-residents who cannot utilise franking credits as Section 3.5 later discusses).

A material piece in the optimal dividend policy equation is the use of Dividend Reinvestment Plans (DRP). Recall from Lowe and Shuetrim (1992) that the average dividend payout ratio in Australia increased from $47 \%$ to $76 \%$ following the introduction of the imputation system in 1987. Holding all else constant, this would have dramatically increased liquidity events in equity capital markets (i.e. firms returning to raise equity). However, this is where DRP's come in. Nicol (1990) noted that prior to 1987 the investment community was largely indifferent about DRPs. But following the change to imputation, DRP announcements were received very positively, with average participation rates of $48 \%$. At this level, a pre-1987 dividend payout ratio of $50 \%$ could be increased to $96 \%$ whilst retaining an equivalent cash position.

Bellamy (1994) examined the extent to which Australian firms attempted to look after their clientele by maintaining sticky dividend franking policies. By examining more than 2,200 dividend events, he found a strong tendency for franking to cluster at either $0 \%$ or $100 \%$ and that payout ratios were consistently higher for firms paying fully franked dividends. Interestingly, prior to 1987, only 25 firms had a DRP in place; however this jumped to more than 120 over the 3 years following imputation reforms. So do company tax imputation credits have a value? Hathaway and Officer (2004) noted that trade in franking credits is prohibited by tax law so it must be inferred by pre- and post-dividend data from capital markets; which leads us to drop-off ratio analysis.

\subsection{Drop-off ratio}

Franking credits must have a value to resident shareholders and we therefore might expect to see evidence of this in the traded price of stocks around ex-dividend dates. Ex-dividend share trades should fall by more than the value of the dividend payment - reflecting the dividend value plus the value of franking credits. Consider this simple observation of an Origin Energy dividend:

- March 2010: Origin Energy declares a 25 cent dividend for 1H10, fully franked with a franking (or company tax) credit of 11 cents, totalling 36 cents;

- Ex dividend date: 2 March 2010.

- 1 March 2010: \$16.99 closing price

- 2 March 2010: $\$ 16.66$ closing price.

- The dividend drop-off $=33$ cents

A 33 cent drop-off is considerably more than the 25 cent dividend, but less than the full dividend plus franking credit value at 36 cents. On any given day there is considerable share market 'noise' making it difficult to delineate stock price movements to any singular piece of information. However, financial economic researchers have designed quantitative methods designed to cancel such noise out. Evidence from the Australian stock market has generally concluded that franking credits are valued. Bellamy (1994) found the mean drop-off ratio for franked dividends (0.8942) exceeded those of unfranked dividends (0.6556). Brown and Clarke (1993) and Hathaway and Officer (2004) also found the market places a positive value on franking credits for Australian firms. In the latter study, ATO data and company Franking Account Balances were used to compile a picture of access to, and utilization of, franking credits. From 1988-2002, about \$265 billion had been paid in company taxes while Franking Account Balances totalled $\$ 77$ billion. Accordingly, $71 \%$ of theoretical franking credits had been accessed 
which unsurprisingly, is very close to the average dividend payout ratio of ASX-listed firms. Additionally, they found that $50 \%$ of distributed credits had been redeemed by taxpayers. Walker and Partington (1999) examined ASX stocks between 1995-1997, a period when some stocks were able to be traded 'cum dividend' and 'ex dividend' after the ex-dividend date. This enabled observations of simultaneous trades in cum and ex-dividend scrip, as distinct from the usual abnormal return analysis, which suffers from lags of up to 18 hours depending on announcement timing. A sample of 1,015 'paired-trades' found an instantaneous drop-off ratio of 1.23 against an implied dividend value of 1.00, and a theoretical fully franked valuation of $1.5625 .{ }^{6}$ Their analysis also incorporated 93 ex-dividend events; paired-trades relevant to the exdividend events had a drop-off ratio of 1.15 .

However, Cannavan, Finn and Gray (2004, p.193) found the value of franking credits to be initially valued at around $50 \%$ of their face value for high-yielding firms, but following the introduction of "the 45-day rule" in 1997 (i.e. trade of franking credits by foreign investors can only occur if the scrip has been held for 45 days around the date of dividend entitlement), they found the value effects of imputation credits to be negligible. The Cannavan et al. (2004) analysis was undertaken at the same time as Hathaway and Officer (2004), and their findings essentially collide. Above all, Cannavan et al. (2004) argued that franking credits do not affect the cost of capital or the value of the firm because short run foreign capital stock trades, thought to be the marginal investor, cannot value franking credits. This raises questions over the mix of investors.

By 2010, there was about A $\$ 1.1$ trillion invested in Superannuation Funds in Australia, and of this, approximately $\$ 546$ billion or $49 \%$ was invested in domestic equities at a compound growth rate of $12.3 \%$, as noted in Figure 2.

Figure 2: Asset allocation of Australian Superannuation 'Funds Under Management'

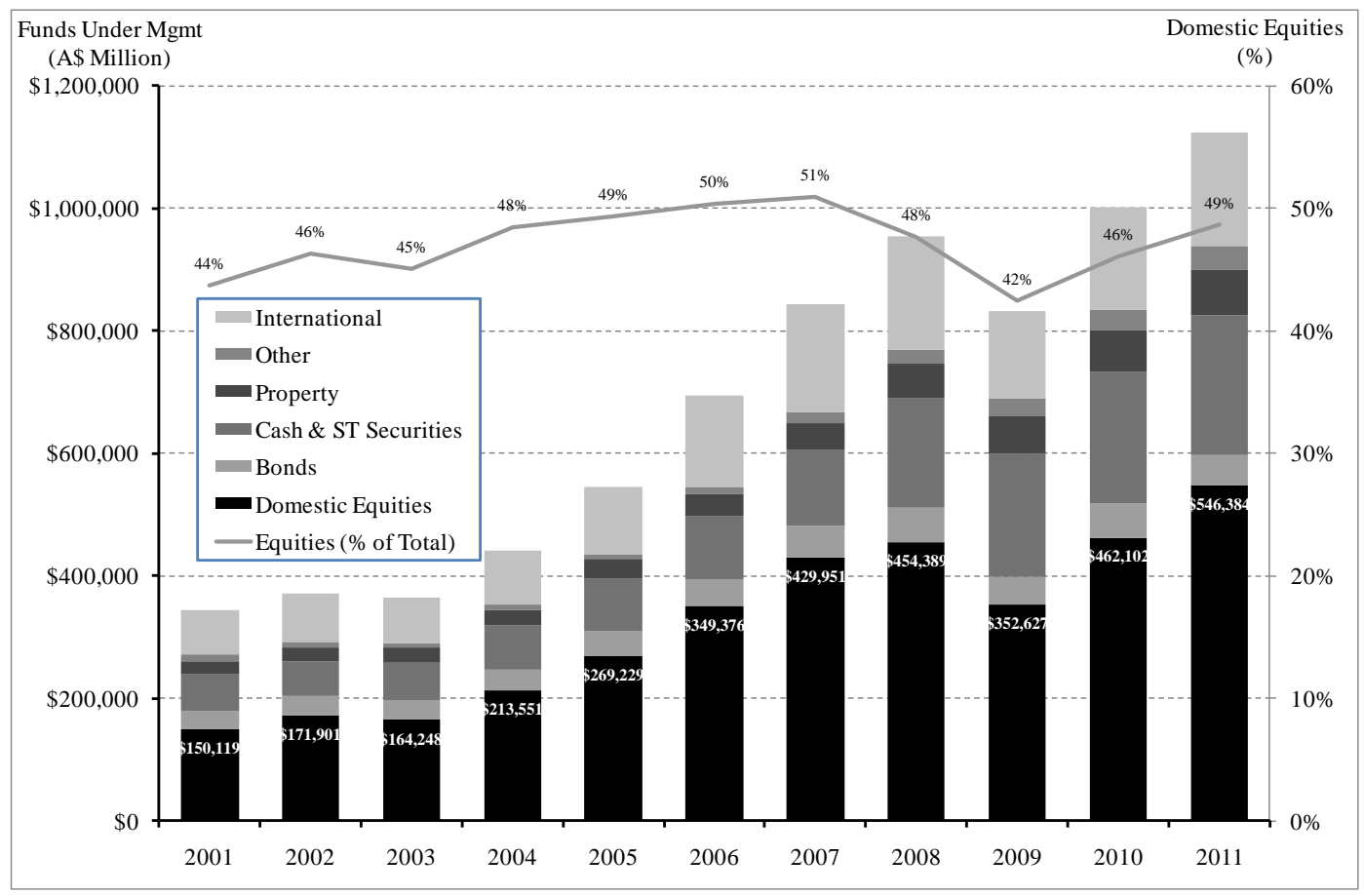

Source: RBA, AGL Energy Ltd.

Simultaneously, foreign capital flows over the period 2001 - 2010 confirm that international equity capital flows are material, averaging about $\$ 36$ billion pa over the last five years as noted in Figure 3. 
Figure 3: Net foreign capital inflows to Australia

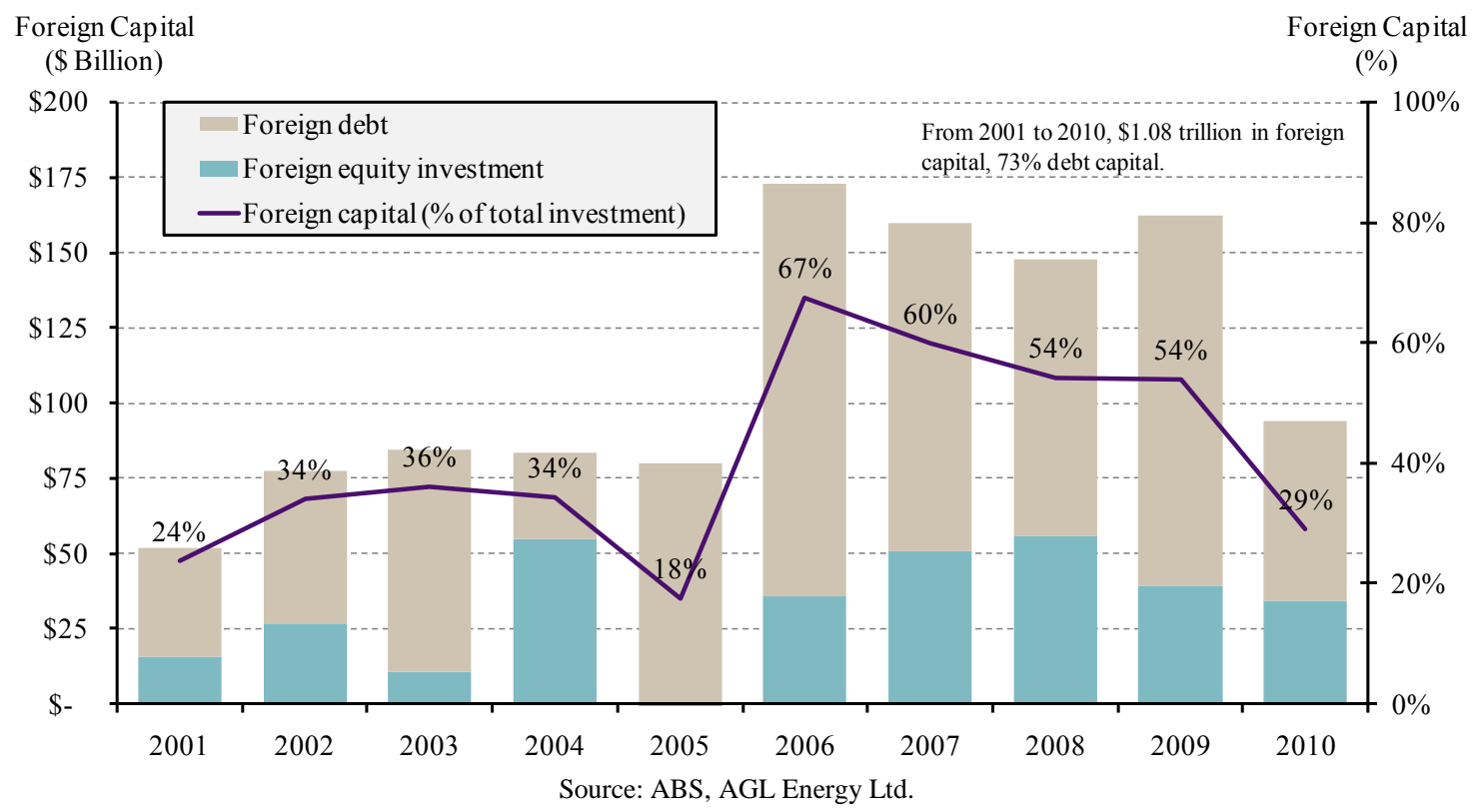

The issue here is that, as Miller and Scholes (1982), Boyd and Jagannathan (1994) and Cannavan et al. (2004) argued, it is the marginal investor who clears stock prices. Marginal investors, which might be thought of as foreign Pension Funds, do not pay conventional local taxes whilst floor traders pay equal taxes on dividends and capital growth, and thus have no distinct preference for franked dividends. Figure 4 illustrates that domestic retail investors in ASX200 equities have fallen from $20 \%$ in 2006 to just $14 \%$ in 2011, while foreign investors increased from $33 \%$ to $41 \%$. The very structure of ownership of course raises questions of agency costs, which are dealt with next.

Figure 4: Ownership of ASX200 equities

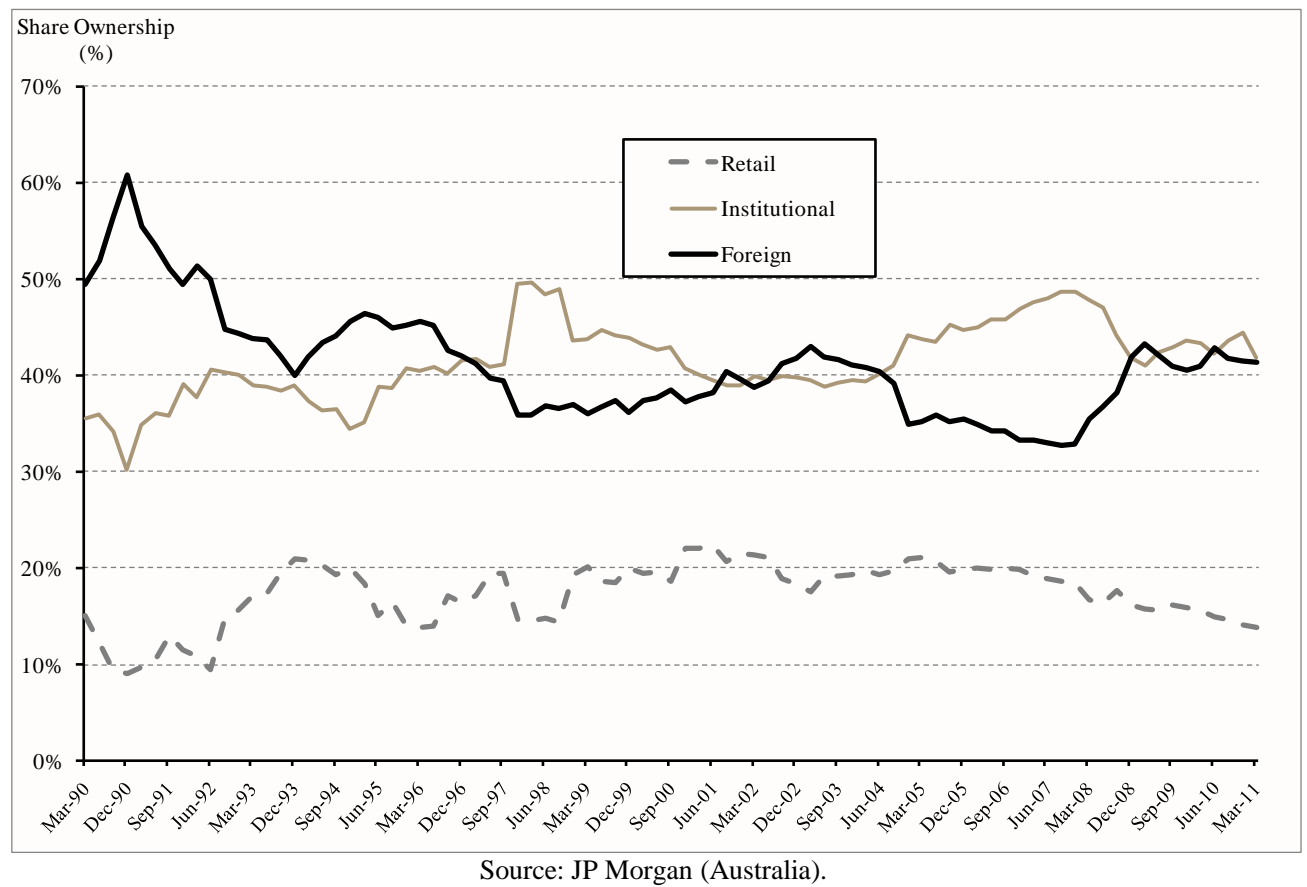

\subsection{Agency costs}

Source: JP Morgan (Australia).

Agency costs have long been a feature of economic theory, dating as least as far back as Berle and Means (1932). Agency costs essentially relate to the separation of management from 
ownership, and the adverse incentives faced by management to maximize their own wealth at the expense of shareholders. The most commonly cited agency costs from a managerial perspective include the pursuit of firm scale by management at any cost, excessive salaries, perquisites and so on. Direct agency costs incurred by owners include monitoring and bonding costs. Such costs represent a deviation away from pure profit maximization (and thus have an opportunity value) and accordingly can be considered a transaction cost that is inherently inefficient.

Rozeff (1982, p.250) observed that adverse management agency costs could be minimized through high dividend payout ratios since one consequence of this is a requirement to tap equity markets on a regular basis for new common equity. Since capital raisings are always associated with the provision of information to investors and underwriters, it follows that the market will have the opportunity to view the firm on a more regular basis, in detail, and at comparatively low cost thus enabling them to monitor the performance of management. Similarly, since the most material managerial agency cost is the pursuit of growth at any cost, it follows that firms with high free cash flows (e.g. energy utilities) are typically categorized as the highest risk. Thus, risks to shareholders can be reduced if management commits to high dividend payout ratios to moderate un-viewed growth - so the theory says.

Smith and Watts (1992) found empirical support for dividend policy and agency costs. In particular, they observed that high-growth firms had low dividend yields, lower leverage, higher executive compensation and employed greater use of stock option plans. They found that high yield stocks were unlikely to make extensive use of stock options for management, implying that one is a surrogate for the other. They also found regulated utilities pay higher dividends, have higher leverage and less use of stock option plans. Interestingly in the case of utilities, they were noted to favour high dividends in order to provide clear evidence about the cost of capital for tariff rate determination decisions.

However, Rozeff (1982) also noted that while a high payout ratio may serve to reduce agency costs, it is likely to increase the transaction costs of raising external equity and hence a tradeoff exists between these two competing 'market imperfection costs'. This tradeoff might also determine the optimal payout ratio for a firm, given investment policy. Key empirical findings in the works by Rozeff (1982) on agency costs were that:

- A high dividend policy tended to be correlated with firms whose past and expected future growth profile had been subdued;

- A high dividend policy was typically associated with firms who had low equity market $\beta$ coefficients (i.e. low sensitivity to movements in the broad market index);

- A high dividend payout ratio was correlated with a highly diversified shareholder base. That is, firms that do not have a substantial portion of their shares held by a small number of dominant shareholders tend to have high dividend payout rates - a finding which was also observed in Jensen et al. (1992, p.261);

- High dividend policy was correlated with low inside ownership; and

- Most importantly, dividend payouts were not randomly distributed.

Lie (2000) examined the relationship between excess cash and (1) special dividend payments, (2) an increase in regular dividend payments and (3) an increase in share repurchases. He found that in all three cases, those firms that undertook additional distributions had higher pre-event cash holdings than their peers in the same industry. And again, the share price reaction in all cases was positive in the event of cash build-up, the view being that the incidence of overinvestment had been reduced.

La Porta et al (2000) tested two agency theories of dividend payments using legal protection as the gauge. Their "Outcome Model" suggested that dividends would be correlated to the extent to 
which the country's legal framework was likely to be effective in protecting shareholder interests (relative to the agency costs of firms). They tested over 4000 companies in 33 countries. The key findings were that common law countries such as the UK, USA and Australia (which often have highly diversified shareholders) have excellent legal protections, as distinct from civil law countries such as Spain, France and Germany.

To test their Outcome Model, one would expect that (1) common law countries have higher dividend payout ratios on average; but (2) high growth firms in common law countries would have low dividend payout ratios, and (3) low growth firms would have high dividend payout ratios. La Porta et al (2000) found consistent support for the Outcome Model. In particular, dividend payout ratios for high growth companies in common law countries were indeed low, but because investors had such strong protection under common law, shareholders were prepared to wait for growth in their total shareholder returns if prospects for the industry and the fundamentals of the firm remained favourable.

\subsection{Information content of dividend announcements}

We have established that taxation may create dividend clienteles for firms, and that franking credits have a value to resident investors who would prefer them to be distributed in a timely manner, other things being equal. We also know that agency costs drive institutional shareholder preferences towards higher dividend policies for low growth companies, which in itself has an inherent 'information content'. Indeed, the 'information content' of dividend announcements has also long been thought of as important. The issue here is to clarify whether the information content of dividends provides some form of assurance over future guidance, or whether it merely confirms announced earnings. More recent quantitative research in this area has revealed enormously important issues for Board Directors.

Stock market reactions to earnings revisions and dividends have long been of interest to financial economists. This is not to imply that Miller and Modigliani's (1961) irrelevance theory is incorrect - the issue is whether information costs associated with dividend announcements exist. Early financial economic thought implied that dividend announcements were a way to get an 'inside view' of the likely future earnings performance of the firm. Miller and Rock (1985) analysed whether firms used dividend announcements to convey private information to investors ${ }^{7}$ by examining the temptation to increase dividends in order to run-up share prices prior to capital raisings. While very short term effects could be identified, ultimately stock prices reverted to true underlying earnings when revealed. Lorderer and Mauer (1992) also examined whether there were benefits in raising dividends prior to capital raisings and found firms were not more likely to raise dividends prior to capital raisings, and that no evidence existed that capital raisings were timed shortly after dividend announcements.

Brown, Finn and Hancock (1977) analysed the information content of Australian company announcements but were unable to isolate the impact of dividends from earnings announcements because in Australia, they are announced simultaneously (unlike in the US). They did find that when earnings and dividend announcements moved in the same direction, they tended to reinforce the effect on share price movements and conversely, where earnings went in one direction and dividends in another, share price reactions were adverse regardless of the variable being increased. ${ }^{8}$ Easton and Sinclair (1989) followed up this study and found that dividend announcements in Australia provided information over and above earnings announcements. And Easton (1991) found that investors are interested in the consistency of market signals, and thus earnings and dividend announcements have an 'interactive effect'. The main thesis was that investors would react negatively if there was a conflict between dividends and earnings.

Balachandran and Nguyen (2004) examined the impact of special dividend announcements in Australia over the 14-year period 1989 to 2002, with a particular focus on the 'surprise element' 
of special dividends. They found a positive price reaction at announcement, which tended to be stronger for 'first time' special dividends. Interestingly, investors viewed special dividends more favourably if they were accompanied by a Dividend Reinvestment Plan.

It seems that announcements of large increases in dividends are often followed by short-run increases in share prices, and that cuts to dividend will be associated with a short-run drop in share price. So returning to Lintner's (1956) seminal work, Board Directors would only increase dividends if they were convinced that such a payout could be sustained. US economists Grullon and Michaely (2002) observed that this has three separate implications:

\section{An unanticipated change in dividend policy should also be followed by a change in share price in the same direction.}

Evidence unambiguously supports this proposition. Grullon, Michaely and Swaminathan (2002) studied a very large sample of US companies, comprising over 7600 announced dividend changes over the period between 1967 and 1998. They had a focus on dividend announcements which represented a change of greater than $+/-12.5 \%$. They found average abnormal returns to share prices over the ensuing three trading days was $+1.34 \%$ for dividend increases, and $-3.71 \%$ for dividend decreases.

Healy and Palepu's (1988) Australian study was directionally consistent, albeit magnified in its results with firms raising dividends experiencing a $+3.9 \%$ increase in share price and decreasing dividends experiencing a $-9.5 \%$ drop in share price. Balachandran and Faff (2004) found that there is a $+5.44 \%$ abnormal return associated with the announcement of special dividends by Australian firms. In summary, the immediate share price reaction occurs in a manner that is directionally consistent with dividend announcements.

Note that firms are unable to "game" these effects by increasing dividends to generate positive stock price reactions. First, an unsustainably high dividend cannot be maintained and the subsequent negative stock price reaction is, on average, materially higher than the increases that are associated with the initial dividend increase. Second, investors have information available to them other than the dividend - their analysis of the full financial accounts of the firm, and any other relevant information, which is likely to reveal whether a proposed dividend change is sustainable.

\section{Unexpected and non-trivial dividend changes should also change market expectations of future earnings of the firms.}

The issue here is when firms increase dividends, do stock analysts revise future earnings upwards? Evidence on this is conflicting. Ofer and Siegel (1987) found a positive relationship between the size of dividend changes, and the forecast earnings of the firm (as reported by stock analysts). But in a later, and much more comprehensive study, Grullon and Michaely (2004) found US analysts revise profits downwards during a month in which increased distributions to shareholders were announced, and most importantly, the greater the dividend, the greater the downward revision.

\section{Changes in dividends should be accompanied by changes in actual future profits in the same direction.}

Against what must surely be dominant thought, the evidence does not support this. Benartzi, Michaely and Thaler (1997) found that US company dividend announcements are lagging indicators. They found that dividend increases were accompanied by increased profit growth in the year of announcement, but found no real evidence that an increase in growth was sustained 
over the next two reporting years. Conversely, in circumstances where dividends were cut, profit growth often rebounded over the following two years.

Recall from the Grullon and Michaely (2002) research that they studied over 7600 dividend events between 1967 and 1998. This study also included financial data of the firms three years before, and after, the dividend event. As with Benartzi et al. (1997), Grullon and Michaely (2002) found that where dividends decreased, Asset Returns actually increased over the following three years and conversely, raising dividends was associated with a demonstrable decline in Asset Returns over the following three year period. These seemingly illogical outcomes, based on a truly vast data set, are worthy of a more fulsome discussion because they have enormously important implications for Board Directors of utility companies, and will therefore be examined in some detail in Section 4.

\section{Dividend policy, industry growth outlook and the cost of capital maturity cycle}

Grullon and Michaely (2002) found that when Board Directors cut dividends, they tended to do so (on average) by $45 \%$. As noted earlier, these firms experienced an immediate abnormal average share return of $-3.71 \%$. Firms who cut their dividends were (on average) "very large" by market capitalization, tended to be more than 19 years old, and had running dividend yields prior to the event of $2.87 \%$. However, in the three years following the dividend cut, Asset Returns increased by $0.44 \%$ after an initial reduction in Asset Returns of $0.51 \%$ in the year of the dividend cut.

On the other hand, firms which increased dividends tended to do so (on average) by $30 \%$. And as noted earlier, this was associated with an immediate abnormal share price return of $+1.34 \%$. The average dividend-increasing firm was also "very large" by market capitalization, was more than 15 years old, with a running dividend yield of $3.46 \%$. After increasing their dividend, these firms experienced an average decline of $0.53 \%$ in Asset Returns over the following three years. Importantly, Grullon and Michaely (2002, p.397) found that firms that increased their dividend the most experienced the greatest decline in profitability. Common thematics associated with firms who increased dividends were:

- An early warning signal for a dividend increasing path was a gradual build-up of cash onbalance sheet;

- After raising dividends, firms tended to experience a reduction in capital expenditure over the following three years;

- Expenditure on Research \& Development was reduced in the years following; but critically,

- While Asset Returns declined, share prices continued to experience positive price drift.

There remains only one variable that could explain such an outcome on economic grounds; a decline in the systematic risk of the firm. This led Grullon and Michaely (2002) to test subsequent movements in the implied weighted average cost of capital (WACC) of dividend increasing/decreasing firms. They used the Fama and French (1993) Three Factor Model to measure WACC estimates. Their hypothesis was proven to be correct; firms that raised dividends experienced a demonstrable reduction in their WACC, from an average $13.2 \%$ prior to the dividend increase to $12.2 \%$ over the three years following the dividend increase. In simple terms, their cost of capital fell by fully 100 basis points. This reduction in systematic risk was also associated with improved bond/credit ratings, and was not related to a change in leverage. They found WACC results to be "mean reverting" in that the WACC of dividend increasing firms moved closer to their rivals. This reduction in the WACC of dividend increasing firms explains positive share price drift in following years. Conversely, firms that cut dividends experienced a $2 \%$ increase in the WACC over the following three years. Grullon and Michaely (2002, p.9-10) 
explained this phenomenon as a "maturity cycle" and likened it to a standard MBA Textbook firm lifecycle theory:

[Sustained increases in dividends to shareholders] are an integral feature of the process a firm undergoes as it moves from a growth phase to a more mature phase. Typically, in a growth phase, a firm has many positive NPV projects available, high capital expenditures, low free cash flows, and high earnings growth. At some point, the firm's growth slows down (e.g. competitors enter the industry) and its economic profit declines. In this phase, capital expenditures decline and the firm generates a large amount of free cash flows. When a firm has fewer growth options and assets play a bigger role in determining its value, the firm's systematic risk declines. Along with the reduction in the firm's risk profile, the firm's Return on Investment declines and so do its economic profits. All else equal, a decline in the Return on Investment should reduce the earnings growth rate of the firm. As investment opportunities decline, the need for resources to undertake new investments should also decline. This decline in investments would lead to an increase in the firm's free cash flows. The potential for management to over-invest is very high when a firm is going through this change in its lifecycle, and hence the incentive for an increase in payout (Grullon and Michaely, 2002, p.9-10).

So when a firm increases its dividends, on average, it is accompanied by a reduction in Asset Returns over the ensuring three year period. So why do firms experience a positive share price drift throughout a period when Asset Returns are declining? The answer is that fundamentally, equity capital markets are reacting to a set of forward cash flows that have become inherently less risky and markets have a distinct tendency to penalize uncertainty and reward clarity.

Second, when firms experience a decline in opportunities, a material "agency risk" arises (per Section 3.6) and in short, equity markets have a heightened concern that management will make reckless investment decisions. So by raising dividends to shareholders, cash-burn is less likely, which in turn is rewarded by positive share price drift. Note also that bond ratings and credit performance of firms improves substantially in the years following enhanced dividends, which underscores the notion that raising dividends is associated with a reduction in the firm's systematic risk.

In addition to dividend policy, there has been empirical research on share buyback effects in Australia. Harris and Ramsey (1995) examined buyback programs of 16 Australian companies between 1989 and 1993 and found a positive share-price response, on average, to the announcement of the buyback. More recent Australian studies tend to focus on why firms initiate share buybacks in the first place. The firm's scrip considered undervalued is the most dominant reason, and in a study by Otchere and Ross (2002), buybacks were associated with a 4\% abnormal return, with the share price of competitors benefiting also.

The majority of distributions to Australian shareholders are in the form of dividends. But changes to the Corporations Law in 1989 and 1995 made it easier for Australian firms to initiate buybacks. As a method of distribution, it has grown rapidly since 1995. Renton (2000) noted that share buybacks totalled only $\$ 770 \mathrm{~m}$ in 1995 while Peirson et al (2006) found this had grown to more than $\$ 7.7$ billion by 2004 , and that this is a global phenomenon; in Germany, Japan, UK, USA and Canada. The primary advantage of share buybacks in Australian is that individual shareholders are able to decide whether to incur capital gains tax (for opt-in schemes). To the extent that Australian firms find themselves with an unexpected surplus in their Franking Balance Account, share buybacks can be structured to stream franking (or company tax) credits back to shareholders, to meet the firm's taxed-biased clientele. 
A key body of closely related work from the US is that associated with 'share re-purchases'. This is especially important to examine when considering US dividend trends, since fundamentally, firms operate under a classical taxation system (the transient Jobs and Growth Tax Relief Reconciliation Act of 2003 notwithstanding). Since shareholders in the US are effectively double taxed, once in the form of company tax, and secondly in the form of personal income tax, it would seem logical for US firms to substantially reduce their dividend policies so that the majority of profits are made through capital gains. This was the topic of examination in Grullon et al. (2000), who examined whether or not firms were running down dividend payouts, and redistributing these earnings through share repurchases to enhance the form and tax efficiency of returns to shareholders. By examining a sample of 14,700 firms over the period 1972-1998, which effectively gave them about 121,000 firm-year observations, they found it was logical to replace dividends with share repurchases on the grounds of taxation. Share repurchases by US corporations tripled between 1984 and 1998, with repurchases increasing from about $1 / 3$ of all distributions to more than $1 / 2$ of all distributions to shareholders. Similarly, the number of firms involved in share repurchases jumped from $31 \%$ in 1972 to $75 \%$ in 1998.

Peirson et al. (2006) noted that in the US, industrials had increased their share repurchase distributions from US $\$ 15.4 b$ to US\$113b between 1985 and 1996. Grullon and Michaely (2002) examined open market share repurchases and observed that in the US, during 1999 and 2000 for the first time firms returned more money to shareholders via repurchases than via dividends. They found that the reasons for increasing share repurchases largely reflected the reasons for increasing dividends; in both instances, the firm's historical profit had increased, but future Asset Returns actually declined in line with the maturity cycle concept. Their study examined 4443 open market share repurchase events between 1980 and 1997. Grullon and Michaely (2004) found that the motivation for changes in dividend payments was largely similar for changes in share repurchase policies. In both cases, an increase was met with declining relative profitability and asset returns, and a decline in the systemic risk of the firm and therefore, the cost of the firm's marginal capital. One key difference between changes to dividends and repurchases was that the former tended to signal a more permanent directional shift.

\section{Dividend Policy, DRP and Equity Raisings of Australian Utilities}

In defining optimality for dividend policy, it is sometimes just as helpful to identify the counterfactual. The turbo-charged dividend policies associated with 'yield stocks', facilitated by the double-stapled security structure, provides important lessons on dividend policy in light of large capital expenditure requirements. Theoretical and empirical observations outlined in Section 2 were magnified in the listed utilities and infrastructure sector in Australia as it relates to the 'tax clientele effect'. Between 2002-2008, the most significant variable in determining dividend policy with yield stocks was not operating performance and future capital commitments, but the availability of firms to continuously tap the bank debt and equity capital markets for fresh raisings. Additionally, DRP's had take-up rates of about 35\%. By combining these three sources of liquidity, utility stocks with high forward capital expenditure commitments could pay extraordinarily high running dividend yields, given the highly favourable capital market conditions.

The marginal capital of yield stocks was raised against asset price inflation, a funding strategy quite familiar to most Australian and US home owners. However, the problem with asset price inflation is its acute correlation with capital market liquidity and interest rate spreads. In this sense, the degree of asset price inflation which could be thought of as 'temporal' comprised the dominant portion. Unsurprisingly, the onset of the Global Financial Crisis and the collapse of Lehman Brothers in the US fundamentally changed capital market conditions, and in turn, asset

prices in the utilities sector. Figure 5 provides an insight into the extent of the collapse in global bank debt liquidity. 
Figure 5: Global syndicated bank debt by Calendar Year - 2004 to 2010

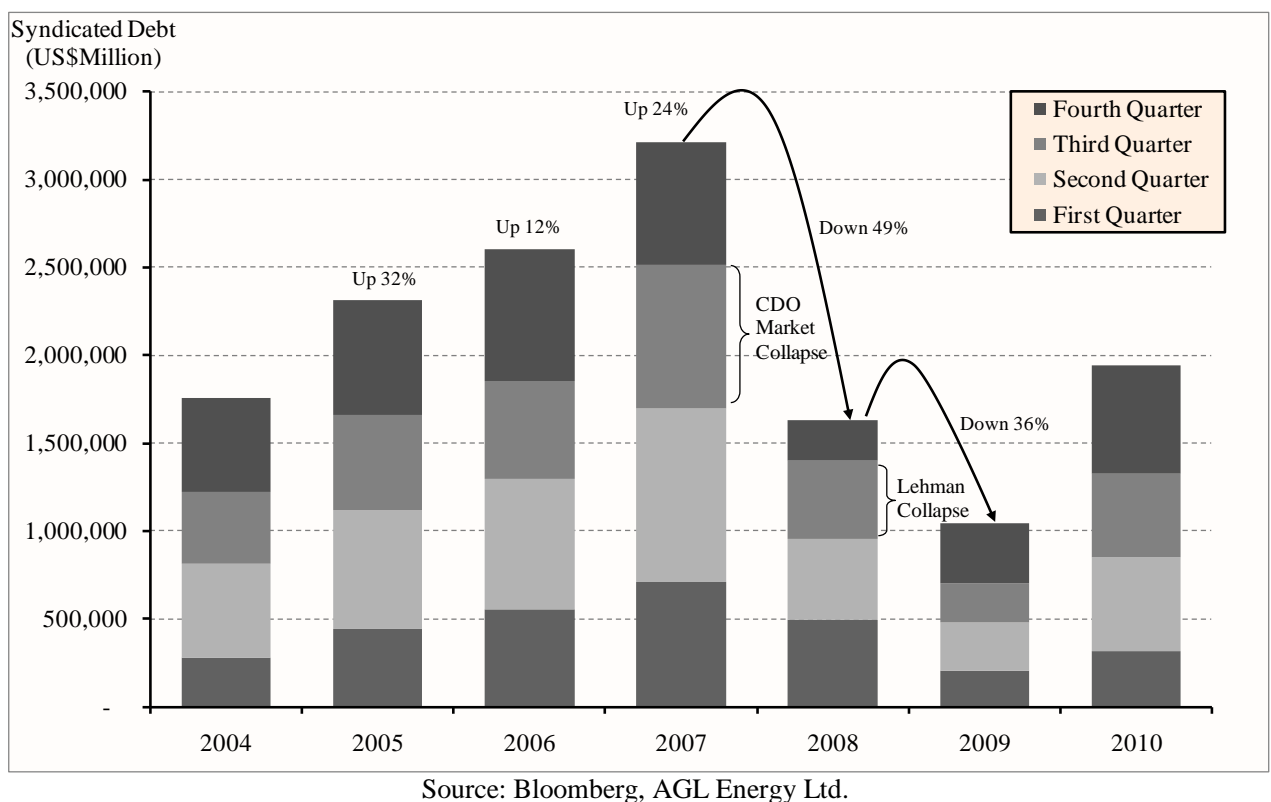

The sharp deterioration in credit markets coupled with steep declines in equity market performance forced utility stocks and especially yield stocks to reappraise dividend policy. The reappraisal process led to a vast number of revised dividend policies and general capital management initiatives. Above all, and as with much of corporate Australia, the equity capital markets were the prime mechanism to deal with the collateral damage and fallout from the Global Financial Crisis, and at very deep discounts.

Figure 6: Australian equity capital market raisings from 1990 to 2009

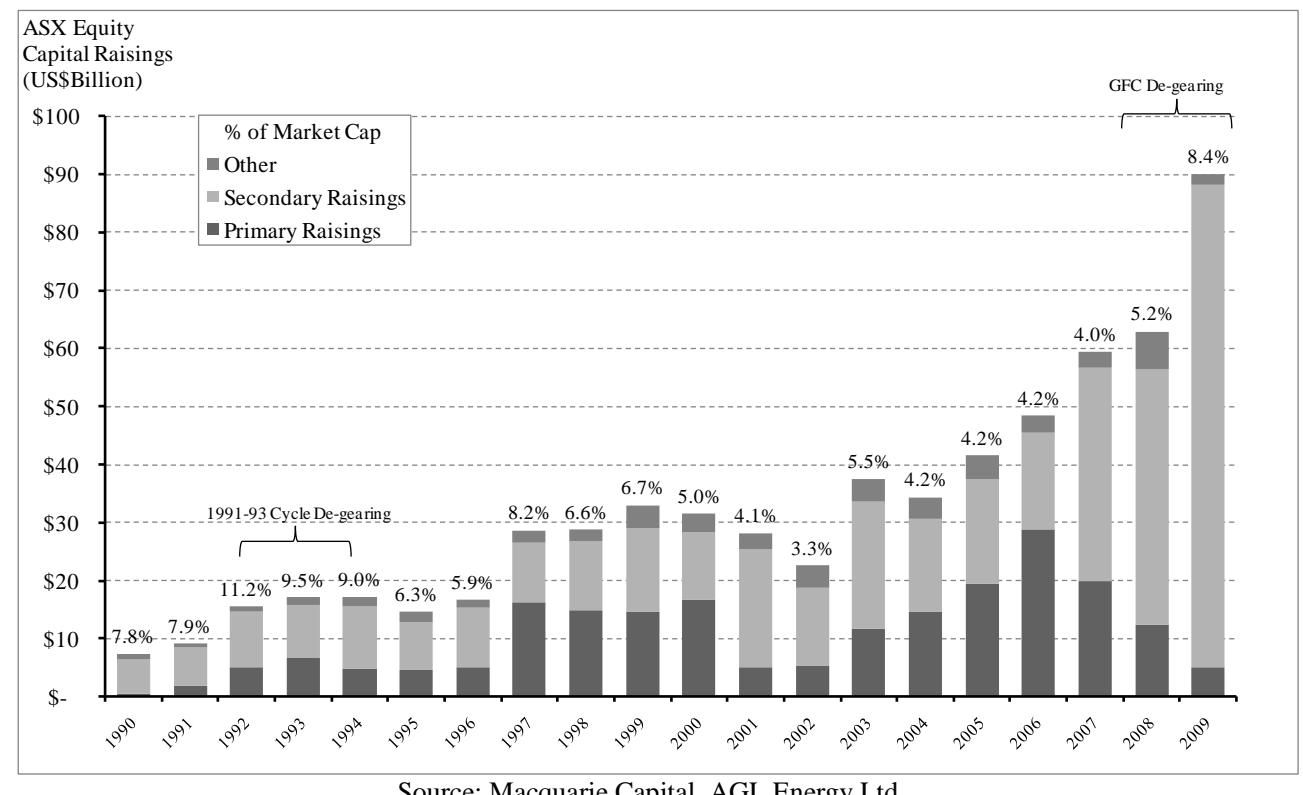

During the last credit squeeze of 1991-1993, Australian firms went into the crisis with average balance sheet gearing of $40 \%$ debt and re-emerged at $31 \%$ on average (based on book values). The 2008-2009 Global Financial Crisis had all the same indicators, corporate Australia entering the cycle with $40 \%$ gearing and by the time the de-gearing process was completed, debt ratios would again be back closer to $30 \%$. Figure 6 provides the quantitative evidence of how this was achieved by providing a 20 year history of capital raisings. Despite being the $12^{\text {th }}$ largest bourse 
in the world, capital raisings in 2009 put the ASX into $3^{\text {rd }}$ place, behind the US and UK respectively.

\subsection{Equity capital raisings, $M \& A$ activity and dividend policy}

Given the favourable equity capital market conditions that existed in Australia between 2002 and 2007, it is not surprising that many firms in the utilities and infrastructure sector achieved stepchanges to their otherwise organic growth profiles through aggressive M\&A activity. This period of sustained growth in equity returns across the ASX is aptly illustrated in Figure 7. The period of collapse is also very evident, with the trough being particularly acute in the months following the Lehman Brothers collapse in Q3 2008.

Figure 7: $\quad$ ASX index between 2000 and 2010

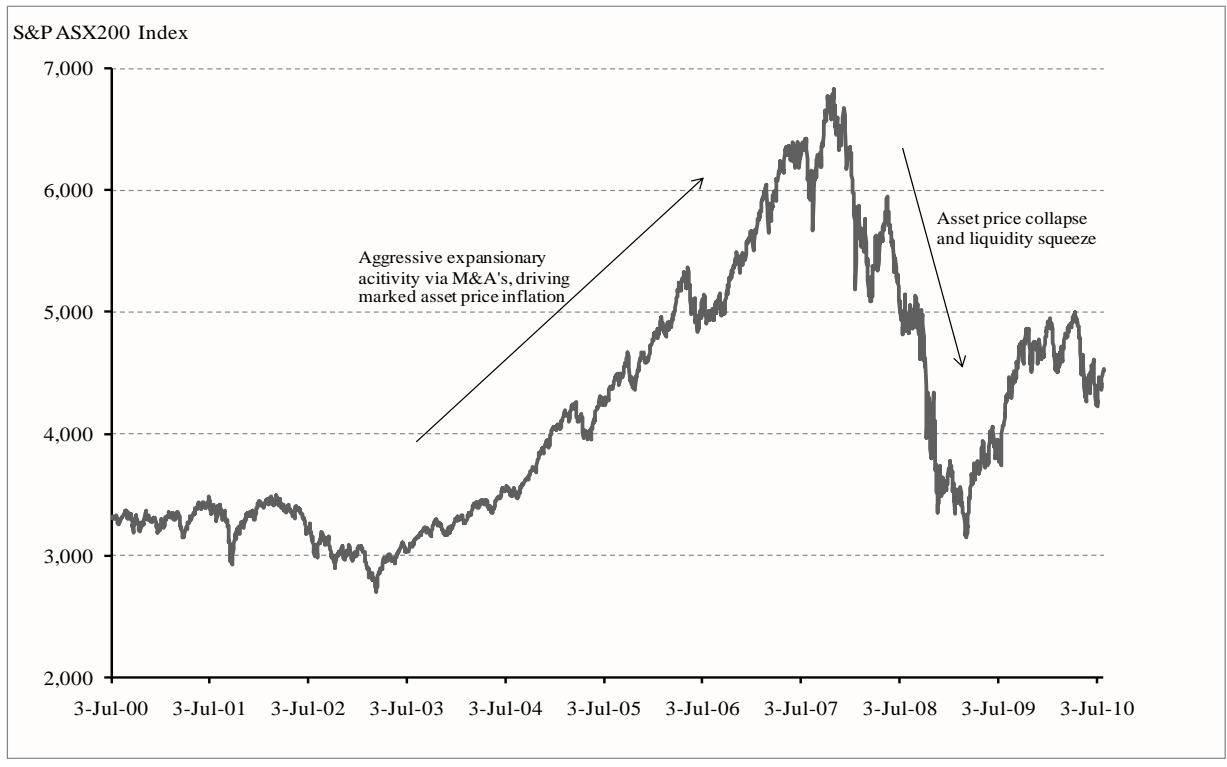

Recall from Figure 5 that during 2002-2007, liquidity in the capital markets progressively accelerated. Competition for assets could be defined as intense as this in turn acted to drive power industry asset prices higher. High prices paid for assets through M\&A activity were presumably undertaken on a value accretive basis but in most cases seemed to be short run cash flow decretive- the well understood 'hockey stick investments' in utilities and infrastructure. This virtually ensured that sector players were forced to adopt a strategy of raising new capital for M\&A activity, and by definition, dividends. The extent to which dividends were financed by the raising of ordinary equity capital in the utilities sector was material, but more striking is the more recent sectoral run-up in dividends, as Figure 8 notes. 
Figure 8: Ordinary equity raised and dividends paid 2002-2010 9

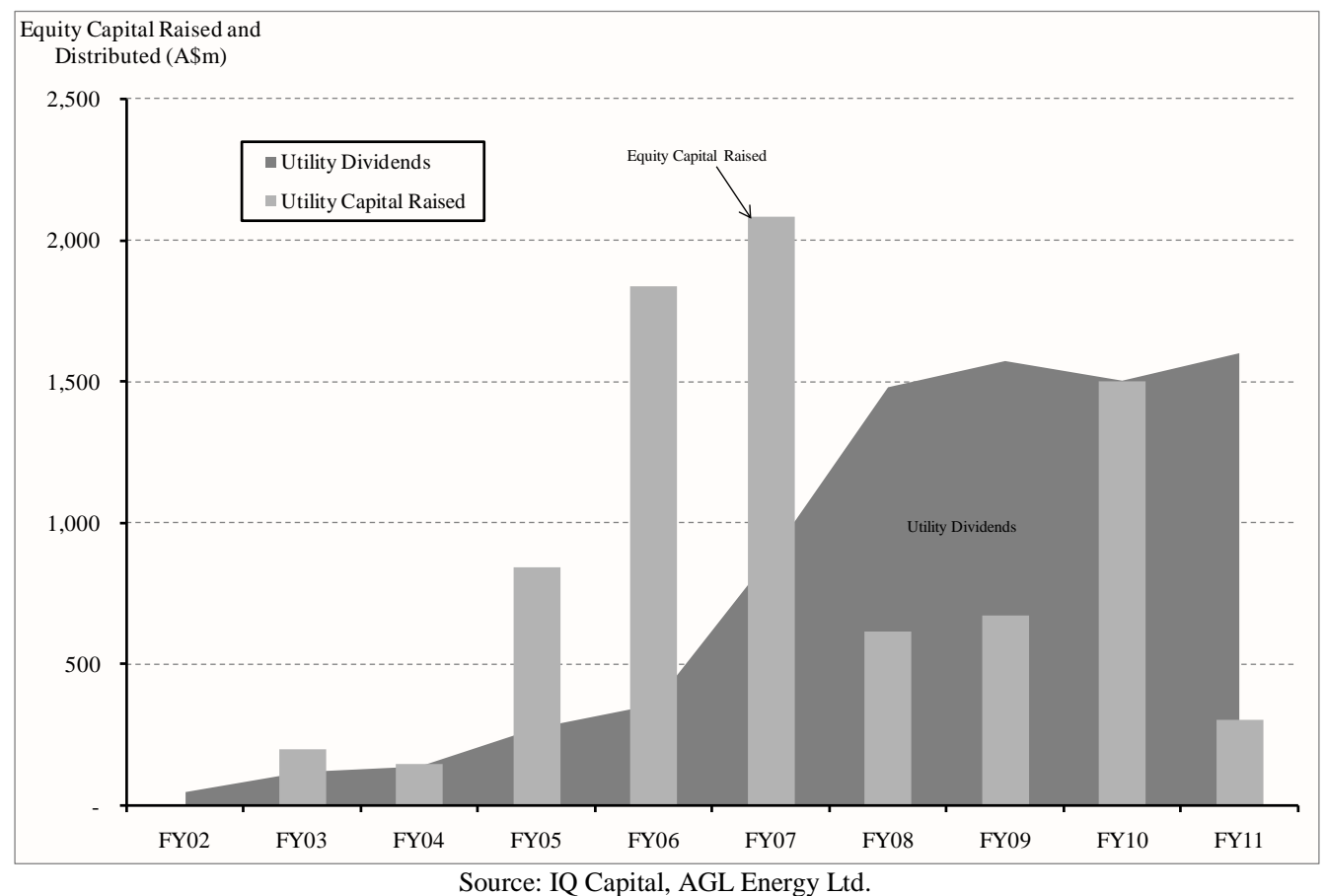

The use of DRPs essentially enhanced dividend payout rates. The extent to which dividends were funded by DRP across the sector between 2002 and 2007 is highlighted in Table 1.

Table 1: Percentage of DRP funds applied to dividends

\begin{tabular}{lcccccc}
\hline $\begin{array}{l}\text { DRP capital raised as a \% of } \\
\text { Distributions }\end{array}$ & 2002 & 2003 & 2004 & 2005 & 2006 & 2007 \\
\hline Infrastruture & $25.9 \%$ & $25.6 \%$ & $40.6 \%$ & $43.6 \%$ & $50.3 \%$ & $23.8 \%$ \\
Utilities & $50.2 \%$ & $65.4 \%$ & $26.5 \%$ & $19.7 \%$ & $16.0 \%$ & $23.8 \%$ \\
\hline Overall & $33.7 \%$ & $34.8 \%$ & $36.7 \%$ & $38.9 \%$ & $41.0 \%$ & $23.8 \%$ \\
\hline
\end{tabular}

However, ultimately the dividend policies of yield stocks became inherently unstable and in the end, intractable in all but a few cases because of the inability to raise new capital and asset price deflation. We expect a recurring thematic with Australian utilities to be substantial capital raising requirements to fund industry growth, and to refinance existing facilities. The extent of this is captured in Table 2, and totals $\$ 94$ billion (on an existing asset base of about $\$ 150$ billion) over the next five years. It seems hardly contentious to suggest that these capital raising requirements should be an important variable considered by Board Directors of all firms in the sector when considering forward dividend policy.

Table 2: $\quad$ Forecast capital requirements for the Australian Utilities Sector - 2010 to 2015

\begin{tabular}{ll}
\hline Capital Requirements & Capital (\$) \\
\hline Refinancing existing network debt facilities & $\$ 33.6$ billion \\
Refinancing existing generation debt facilities & $\$ 9.4$ billion \\
Capital investment on existing and new network infrastructure & $\$ 43.0$ billion \\
Capital investment on existing and new power plants & $\$ 8.2$ billion \\
\hline Total Capital & $\$ 94.1$ billion \\
\hline
\end{tabular}

Source: esaa (2010)

\section{An analysis of dividend policies of energy utilities}

It is not easy to make direct business comparisons amongst energy utilities. This is due to regulatory settings, market design, industry consolidation, and the emerging split between 
conventionally vertical integrated utilities (incorporating both the network infrastructure, power stations and retailing), and merchant utilities (which have shed their interests in the highly regulated 'poles and wires'). Stock analysts that cover Australia's listed merchant utilities, Origin Energy and AGL Energy, do not generally contrast these businesses with international peers. Nonetheless, we have opted to analyse utility businesses across the US, Europe and Australia. The main focus of the peer group analysis is dividend payout ratios as a percentage of earnings against gearing. This analysis is presented in Table 3 .

Regulated utilities have higher gearing, and higher dividends than merchant utilities: analysis shows that regulated utilities have an average gearing of 55\% debt to debt plus equity, and dividend payout ratios of $71 \%$. Merchant Utilities have average gearing of $42 \%$ and dividend payout ratios of $46 \%$. This fundamentally reflects the difference in expected market risk, with regulated utilities having comparatively limited downside revenue exposure, thus enabling higher gearing and higher dividend payout ratios.

US Utilities payout the lowest dividends on average, and have the highest gearing, on average: analysis shows that US utilities pay out a lower portion of earnings, averaging $43.8 \%$ across the listed entities, with average gearing of 52.6\%. But this result is of course weighed down by the non-trivial number of entities currently paying zero dividends. Nonetheless, taken as a whole this result is consistent with empirical studies where higher fixed debt payments are associated with lower dividend payout ratios. The fact that average US dividends are lowest is also not entirely surprising given the classical taxation system. In some respects, what is surprising is the extent to which dividends are actually paid. Only two Utilities utilized a share buyback scheme over recent years (which has the effect of minimising tax costs in the hands of US resident shareholders), although both were substantial at US\$500m and US\$750m. Low payout ratios of US Utilities, especially in the IPP space, can also be traced to the deeply cyclical nature of the sector over the past decade, in particular, the subsequent overbuild that led to a collapse in spark spreads, and in turn, a number of financial distress events. ${ }^{10}$

Australian Network Utilities have the highest gearing, and highest dividends: gearing of Australian transmission and distribution network utilities is highest, averaging about $62.2 \%$, and also, have very high dividend payout ratios averaging about $79 \%$. This almost diametrically opposed financial position reflects the extremely favourable regulatory environment, which is characterised by virtually bullet-proof revenue streams. Of course, payout ratios are distinctly at odds with our investment megacycle thematic.

EU Utilities payout ratio is about 50\%: regulated and merchant utilities in the EU seem to gravitate towards a 50\% payout ratio. European utilities have also long been characterised by much more conservative gearing levels, at about 39\% - a trend that can be traced back at least as far back as the commencement of energy sector reforms. Gearing ratios in the EU have no doubt been maintained at lower levels given the high degree of M\&A activity that occurred in the 2000s.

Australian Merchant Utilities have the highest merchant payouts: The dividend payout ratios of Australia's listed merchant utilities are very high at $60+\%$, with commensurately lower gearing levels. Gearing levels are currently below their usual 'target' of about $30 \%$ debt to debt plus equity (which is an investment-grade credit rating constraint), reflecting a recent run of noncore asset sell-downs by both merchant utilities. 
Table 3: Analysis of dividend payout ratios and gearing levels

\begin{tabular}{|c|c|c|c|}
\hline & $\begin{array}{r}\text { Implied } \\
\text { Div Yield }\end{array}$ & $\begin{array}{r}\text { Corporate } \\
\text { Gearing }\end{array}$ & $\begin{array}{r}3 \text { Year Average } \\
\text { Div / NPAT }\end{array}$ \\
\hline \multicolumn{4}{|l|}{ US Utilities } \\
\hline Ameren Corporation & $5.3 \%$ & $47.2 \%$ & $66.9 \%$ \\
\hline American Electric Power & $4.4 \%$ & $55.9 \%$ & $61.5 \%$ \\
\hline DTE Energy & $4.3 \%$ & $53.0 \%$ & $60.7 \%$ \\
\hline Dominion Resources & $3.8 \%$ & $59.5 \%$ & $54.9 \%$ \\
\hline Duke Energy Corp & $5.1 \%$ & $41.0 \%$ & $71.9 \%$ \\
\hline Entergy Corp & $4.8 \%$ & $56.1 \%$ & $52.6 \%$ \\
\hline Exelon Corp & $4.9 \%$ & $48.1 \%$ & $59.0 \%$ \\
\hline FirstEnergy & $5.0 \%$ & $59.1 \%$ & $66.3 \%$ \\
\hline Edison International & $3.3 \%$ & $49.8 \%$ & $42.7 \%$ \\
\hline Southern Company & $4.4 \%$ & $53.8 \%$ & $73.9 \%$ \\
\hline Westar Energy & $4.6 \%$ & $55.9 \%$ & $67.5 \%$ \\
\hline Progress Energy Inc & $5.1 \%$ & $54.9 \%$ & $80.5 \%$ \\
\hline Constellation Energy & $2.5 \%$ & $29.2 \%$ & $23.5 \%$ \\
\hline NextEra Energy & $3.5 \%$ & $58.8 \%$ & $46.1 \%$ \\
\hline NV Energy & $2.9 \%$ & $60.6 \%$ & $47.5 \%$ \\
\hline Calpine Corp & $0.0 \%$ & $66.8 \%$ & $0.0 \%$ \\
\hline AES Corp & $0.0 \%$ & $58.6 \%$ & $0.0 \%$ \\
\hline NRG Energy Inc & $0.0 \%$ & $49.0 \%$ & $0.6 \%$ \\
\hline Dynegy & $0.0 \%$ & $62.1 \%$ & $0.0 \%$ \\
\hline GenOn Energy & $0.0 \%$ & $33.1 \%$ & $0.0 \%$ \\
\hline US Average & $3.2 \%$ & $52.6 \%$ & $43.8 \%$ \\
\hline \multicolumn{4}{|l|}{ EU Utilities } \\
\hline Fortum Oyj & $5.0 \%$ & $41.8 \%$ & $64.7 \%$ \\
\hline Scottish \& Southern Energy & $5.3 \%$ & $49.5 \%$ & $54.9 \%$ \\
\hline International Power plc & $3.4 \%$ & $50.0 \%$ & $40.2 \%$ \\
\hline Drax Group ple & $6.4 \%$ & $0.0 \%$ & $51.5 \%$ \\
\hline Verbund AG & $1.9 \%$ & $47.3 \%$ & $50.3 \%$ \\
\hline CEZ & $6.1 \%$ & $37.0 \%$ & $58.7 \%$ \\
\hline Electricite de France & $4.2 \%$ & $46.3 \%$ & $62.8 \%$ \\
\hline E.ON AG & $7.6 \%$ & $32.9 \%$ & $57.3 \%$ \\
\hline RWE AG & $9.0 \%$ & $39.4 \%$ & $57.1 \%$ \\
\hline Enel & $1.5 \%$ & $33.2 \%$ & $29.5 \%$ \\
\hline Vattenfall & $4.9 \%$ & $51.9 \%$ & $49.3 \%$ \\
\hline Centrica ple & $4.4 \%$ & $37.9 \%$ & $49.0 \%$ \\
\hline EU Average & $5.0 \%$ & $38.9 \%$ & $52.1 \%$ \\
\hline \multicolumn{4}{|l|}{ Australian Merchant Utilities } \\
\hline AGL Energy & $4.1 \%$ & $10.6 \%$ & $62.3 \%$ \\
\hline Origin Energy & $3.2 \%$ & $22.9 \%$ & $61.3 \%$ \\
\hline Australian Merchant Average & $3.7 \%$ & $16.7 \%$ & $61.8 \%$ \\
\hline \multicolumn{4}{|l|}{ Aus tralian Network } \\
\hline SP Ausnet & $8.6 \%$ & $58.9 \%$ & $82.2 \%$ \\
\hline Energex & & $60.4 \%$ & $80.0 \%$ \\
\hline Ergon & & $58.0 \%$ & $86.4 \%$ \\
\hline Powerlink & & $62.4 \%$ & $79.5 \%$ \\
\hline Energy Australia & & $75.0 \%$ & $82.2 \%$ \\
\hline Country Energy & & $65.1 \%$ & $26.6 \%$ \\
\hline Integral Energy & & $67.4 \%$ & $76.3 \%$ \\
\hline APA Group & $8.0 \%$ & $73.1 \%$ & $101.2 \%$ \\
\hline Spark Infrastructure Group & $10.2 \%$ & $54.7 \%$ & $147.1 \%$ \\
\hline Australian Network Average & $8.9 \%$ & $62.2 \%$ & $79.5 \%$ \\
\hline TOTAL AVERAGE & $4.3 \%$ & $47.0 \%$ & $53.2 \%$ \\
\hline
\end{tabular}

Source: Deutsche Bank (Australia), AGL Energy Ltd.

A comparison of payout ratios and running yields for the firms that comprise the peer group (excluding zero dividend-paying utilities) is presented in Figure 9. This cross-sectional analysis is limited by the fact that each firm will have unique firm-specific issues driving dividend decisions. But the substantive point here is that for particular firms with a given capital requirement and target capital structure, higher dividend payouts will lead to more equity raisings. A requirement to undertake more equity capital market raisings than less, given the current macroeconomic environment (which is unlikely to resolve itself quickly), would not seem to be desirable from a capital management perspective if reasonable alternatives existed. 
Figure 9: International Peer Group Payout Ratio and Corporate Gearing

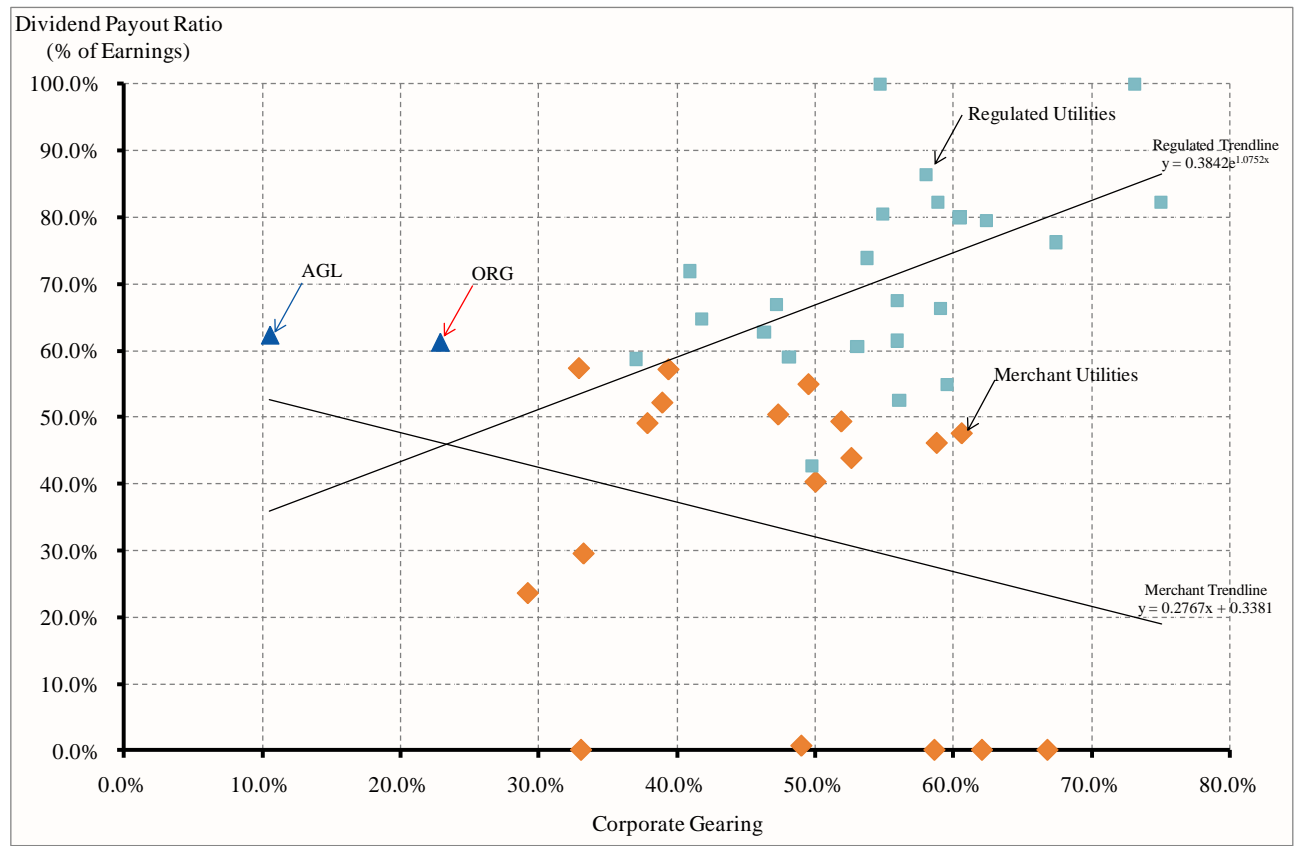

\section{Concluding remarks on dividend optimality for energy utilities}

This article has found that the current dividend policy of merchant and regulated utilities in Australia is to pay about $60 \%$ and $80 \%$ of earnings, respectively. The dividend policies of European utilities seem to gravitate towards the 50-60\% range. Dividend policies of US utilities span a wide range that averages $44 \%$, although once zero dividend paying firms are excluded, the payout ratios resemble Australian merchant utilities at about $60 \%$.

In Australia at least, energy utilities have 'historically' orchestrated dividend policies in which company tax franking credits have been distributed to shareholders as they materialized, and payout ratios have been particularly 'sticky'. These dividend policies can therefore be described as clientele friendly, tax optimizing, and from a capital structure perspective, historically appropriate. But as this article was being drafted, an issue that kept exercising the minds of the authors was the cyclical interactions between an investment megacycle, Australia's structural reliance on foreign capital, ongoing global risks to capital market liquidity, and dividend payout ratios expanding at the same rate as profits.

And the investment megacycle is not, of course, an Australian-centric phenomenon. For example, in Britain, the expected draw on capital for their power system from 2011-2020 is thought to be of the order of $£ 200-£ 250$ billion. $^{11}$ And the International Energy Agency’s 2011 World Energy Outlook identified a global capital investment program of more than US\$38 trillion to 2035 of which US $\$ 17$ trillion relates specifically to the power sector. ${ }^{12}$

A number of large utilities that the authors contacted during the course of this research - from Europe, the US and Asia - reported similar capital tasks to their Australian counterparts, due to some or all of aged network infrastructure replacement, smart meter roll-outs, meeting renewable targets, replacing aged power plant equipment, and in the case of Asia, accelerating load growth.

So what guidance for setting future dividend policies has been revealed throughout this article for those utilities facing an investment megacycle? To begin with, we have not, nor would we suggest, an outright reduction in the absolute dividend payments of utilities as measured by dividends per share. Given the volatility in the share market at the time of writing, doing so 
would clearly be unhelpful. But over the long run, as share market volatility moderates and on the proviso that investments forming part of the megacycle are providing solid returns to equity, reducing the rate of dividend growth, and continuing with Dividend Reinvestment Plans to enhance capital retention, seems to us worthy of serious consideration in order to reduce utility exposures to persistent and non-trivial debt and equity capital raisings.

The basic thematic underpinning our analysis of dividend policy settings is that there is a tradeoff between (a) paying higher dividends to satisfy clientele and provide positive signals vs. (b) retaining cash for capital investments. Consistent with the results of Figure 1 and the Grullon and Michaely (2002) maturity cycle, historically, energy utilities have given more weight to (a) which is an entirely appropriate policy when growth prospects are limited. Going forward, however, our thesis is that where forward sectoral investments clear the relevant financial hurdle rates, retaining cash for the investment megacycle will be important. ${ }^{13}$ This article has touched seldom and lightly on the very substantial timing risks and costs of equity raisings due to underwriting fees, and the fact that new scrip is inevitably issued at a discount to prevailing prices (due to asymmetric information effects). In adverse capital market conditions, discounts associated with new scrip issues can and have been excruciatingly high.

Let us conclude by summarising the key lessons that have been learned by financial economic researchers over the last 60 years in relation to dividends, and dividend policy changes:

- Board Directors and Executives advising Boards should target a smoothed dividend policy, with earnings-related adjustments made at only part of envisaged future changes. In an ideal world which of course rarely exists in practice, sharp, sudden or erratic changes to dividend policy should be avoided;

- In a perfect capital market (a world without taxation or frictional costs, no agency costs and symmetric information) dividends are actually irrelevant. The most obvious market imperfection is taxation. What research can't explain is why dividends were paid at all under a classical taxation system ${ }^{14}$ such as that which exists in the US (at least until the 'transient' Jobs and Growth Tax Relief Reconciliation Act of 2003 was passed, and extended on a short-term basis);

- There is in fact a natural clientele for high dividend stocks, and low dividend / high capital growth stocks, although their economic significance is negligible;

- We know that under dividend imputation systems of taxation and other similar variants such as those that exist in Australia, New Zealand, Canada, Japan and many European countries, resident shareholders prefer franked dividends because the value of franking credits have a time value. Other things being equal, energy utilities in such countries should therefore ensure that company tax franking credits are distributed to shareholders as they arise;

- The implementation of DRP's is especially useful as they enable firms to pay higher dividends whilst retaining earnings;

- We know that the announcement of special dividends receives a positive share price reaction and that an associated Dividend Reinvestment Plan is also viewed favourably; ${ }^{15}$

- Large changes to dividend policy can, and most likely will, cause short-run changes in share prices in the same direction. This is predominantly related to the information content of earnings, not dividend policy itself;

- Prior to changing dividend policy, Board Directors should provide as much forewarning as possible and take care to ensure that the basis for the action is not misinterpreted (i.e. in this instance, clarify that it is driven by capital needs of the investment megacycle rather than an expected change to future earnings);

- While dividend policy is most typically based on past conditions, it must be biased towards future conditions when setting the payment rate. The investment community both understands and expects this; 
- For energy utilities facing an investment megacycle, shifting dividend payout ratios downwards by a full 10 percentage points over time (for example shifting Australian Merchant Utility payout ratios from the current $60 \%$ to $50 \%$ payout while not reducing the dividend as measured in cents per share) would not appear to violate any of Lintner's (1956) parameters. Such a change should be considered 'long run favourable'. The reason for this is that dividend streams would remain fundamentally smoothed and exhibit stability and growth (albeit at lower growth rates). Given the industry outlook, it would seem entirely unlikely that such a policy would require reversal over a two year timeframe;

- The information content of such a policy change would, based on empirical analysis, seem most unlikely to adversely affect utility stock prices because this involves incremental (not radical) change. An initial very short-run negative reaction is possible and almost likely, bearing in mind the evidence of abnormal negative share price returns over a 3-day observation period when a rising earnings announcement conflicts with a falling dividend. But the evidence from the financial economics literature is clear that over the long run, dividends are unambiguously a lagging indicator;

- Recall that raising dividends is typically associated with falling Asset Returns and a falling WACC as growth options for the firm begin to moderate and the systematic risk of the industry is reduced, which Grullon and Michaely (2002) observed to be a maturity cycle. Conversely and more importantly, where dividends were reduced, firms increased capital expenditure and Asset Returns (with a commensurately rising WACC);

- The evidence in front of many energy utilities in Australia, the US and Europe is that, whereas the industry originated from a mature state with limited growth options in the 1990s following over-investment during the 1980s, the decade to come will be characterized by the need to replace aged infrastructure, the rapid acceleration of renewable generation investments, carbon pricing and therefore an unprecedented change-out in the capital stock through switching to cleaner fuels; and the evolution of a digital electricity system (i.e. smart meters and the smart grid, including the emergence of Demand Response technologies). There does not appear to be anything "mature" about the industry's outlook;

- Our analysis of global syndicated debt markets highlighted a rapid deceleration and subpar recovery of bank debt availability, and while conditions have improved from cyclical lows, they remain subdued which may place a heightened load on equity raisings to finance growth; and

- Agency theory is clear that firms with low growth prospects experience the most pressure, and are therefore most rewarded, for raising dividends. Conversely, firms with solid growth prospects operating in common law countries tend to be supported by their shareholders; the inherent legal protection afforded to shareholders (e.g. in countries such as Australia, Canada, New Zealand, the US and UK amongst others) means that shareholders are prepared to wait for the total shareholder return prospects of the firm.

The events of the Global Financial Crisis are a timely reminder of the fragility of capital market liquidity. As the regulated industry continues to replace aging networks and pursue smarter grids, and as the merchant industry begins to change-out the incumbent plant stock with cleaner generating capacity, non-trivial multi-period irreversible capital commitments become inevitable - an investment megacycle. Retaining as much flexibility in dealing to those commitments would seem to be extremely important in determining forward dividend policy. The costs of moderating dividend growth are likely to be trivial beyond the very short run, and will generate benefits in terms of greater balance sheet flexibility and reduced equity raising costs in the future.

\section{References}

Asquith, P. and Mullins, D. (1983), "The impact of initiating dividend payments on shareholders", Journal of Business, January 1983, pp.77-96. 
Balachandran, B. and Faff, R. (2004), "Special dividends, bonus issues and on-market buybacks: signaling in an imputation environment", Finance Letters, 2(1): 23-26.

Balachandran, B. and Nguyen, T. (2004), "Signaling power of special dividend in an imputation environment", Accounting and Finance, 44(3): 277-297.

Ball, R., Brown, P., Finn, F. and Officer, R. (1979), "Dividends and the value of the firm: evidence from the Australian equity market", Australian Journal of Management, April 1979, pp.13-26.

Bellamy, D. (1994), "Evidence of imputation clienteles in the Australian equity market", Asia Pacific Journal of Management, 11(2): 275-287.

Benartzi, S., Michaely, R. and Theler, R. (1997), "Do changes in dividends signal the future or the past?", Journal of Finance, 52(3): 1007-1034.

Berk, J., Green, R., and Naik, V., 1999 Optimal Investment, Growth Options and Security Returns, Journal of Finance 54(5), 1999; 1553-1607.

Berle, A. and Means, G. (1932), The Modern Corporation and Private Property, MacMillan, New York.

Black, F. and Scholes, M. (1974), "The effects of dividend yield and dividend policy on common stock prices and returns", Journal of Financial Economics, May 1974, pp. 1-22.

Boyd, J. and Jagannathan, R. (1994), "Ex-dividend price behavior of common stocks", The Review of Financial Studies, 7(4): 711-741.

Brown, P. and Clarke, A. (1993), "The ex-dividend day behavior of Australian share prices before and after dividend imputation", Australian Journal of Management, 18(1): 1-40.

Brown, P., Finn, F. and Hancock, P. (1977), "Dividend changes earnings reports and share prices: some Australian findings", Australian Journal of Management, October 1977, pp.127-147.

Cannavan, D., Finn, F. and Gray, S. (2004), "The value of dividend imputation tax credits in Australia", Journal of Financial Economics, 73(2004): 167-197.

Easton, S. and Sinclair, N. (1989), "The impact of unexpected earnings and dividends on abnormal returns to equity", Accounting and Finance, 29(1): 1-19.

Easton, S. (1991), "Earnings and dividends: is there an interaction effect?", Journal of Business Finance and Accounting, 18(2): 255-266.

Fama, E. and French, K. (1993), "Common Risk Factors in the Returns on Stocks and Bonds", Journal of Financial Economics, 33 (1): 3-56.

Finon, D. (2008), "Investment risk allocation in decentralised markets: the need of long-term contracts and vertical integration”, OPEC Energy Review, 32(2): 150-183.

Grullon, G. and Michaely, R. (2000), "Dividends, share repurchases and the substitution hypothesis", available at http://papers.ssrn.com/sol3/papers.cfm?abstract_id=222730

Grullon, G. and Michaely, R. (2002), "The information content of share repurchase programs", available at http://papers.ssrn.com/sol3/papers.cfm?abstract_id=206328

Grullon, G., and Michaely, R. 2004. "The Information Content of Share Repurchase Programs," Journal of Finance, American Finance Association, vol. 59(2), pages 651-680, 04.

Grullon, G., Michaely, R. and Swaminathan, B. (2002), “Are dividend changes a sign of firm maturity?", Journal of Business, 75(3):387-423. 
Hamson, D. and Ziegler, P. (1990), "The impact of dividend imputation on firms' financial decisions", Accounting and Finance, November 1990, pp.29-53.

Harris, T. and Ramsey, I. (1995), “An empirical investigation of Australian share buy-backs", Australian Journal of Corporate Law, 4(4): 393-416.

Hathaway, N. and Officer, R. (2004), "The value of imputation tax credits", available at http://www.agl.com.au/Downloads/050427_App-1-Imputation-Tax-Credits\%E2\%80\%93Hathaway-andOfficer_Corporate_Government-Submissions.pdf

Healy, P. and Palepu, K. (1988), "Earnings information conveyed by dividend initiations and omissions", Journal of Financial Economics, 21(2): 149-175.

Howard, P. and Brown, R. (1992), "Dividend policy and capital structure under the imputation tax system: some clarifying comments", Accounting and Finance, May (1992): 51-61.

Joskow, P. (2006), "Competitive electricity markets and investment in new generating capacity", Center for Energy and Environmental Policy Research Working Paper 06-009.

Kellow, A. (1996), Transforming Power - the Politics of Electricity Planning, Cambridge University Press, Cambridge.

La Porta, R., Lopez-de-Silanes, F., Shleifer, A., and Vishny, R. (2000_, “Agency Problems and Dividend Policies around the World", Journal of Finance, 55, 1-33.

Lie, E. (2000), "Excess Funds and Agency Problems: An Empirical Study of Incremental Cash Disbursements," Review of Financial Studies, 13, 219-248.

Lintner, J. (1956), "Distribution of incomes of corporations among dividends, retained earnings and taxes", American Economic Review, May 1956 pp. 97-113.

Llewellen, W., Stanley, K., Lease, R. and Schlarbaum, G. (1978), "Some direct evidence on the dividend clientele phenomenon", Journal of Finance, December 1978, pp.1385-1399.

Lorderer, C and Mauer, D, (1992), "Corporate Dividends and Seasoned Equity Issues: An Empirical Investigation," Journal of Finance 47, 201-225.

Lowe, P. and Shuetrim, G., (1992), "The Evolution of Corporate Financial Structure: 1973-1990," RBA Research Discussion Papers rdp9216, Reserve Bank of Australia

Miller, M. (1977), “Debt and taxes”, Journal of Finance, May 1977, pp. 261-275.

Miller, M. and Modigliani, F. (1961), "Dividend policy, growth and the valuation of shares", Journal of Business, October 1961, pp.411-433.

Miller, M. and Rock, K. "Dividend policy under asymmetric information", Journal of Finance, September 1985, pp. 1031-1051.

Miller, M. and Scholes, M. (1978), "Dividends and taxes", Journal of Financial Economics, December 1978, pp.333-364.

Miller, M. and Scholes, M. (1982), "Dividends and taxes: some empirical evidence", The Journal of Political Economy, 90(6): 1118-1141.

Nicol, R. (1992), “The dividend puzzle: au Australian solution?”, Australian Accounting Review, November 1992, pp.42-55.

Ofer, A. and Siegel, D., (1987), "Corporate financial policy, information, and market expectations", Journal of Finance, 42, 889-911. 
Otchere, I. and Ross, M. (2002), "Do share buy-back announcements convey firm-specific or industry-wide information? A test of the undervaluation hypothesis", International Review of Financial Analysis 11, 511531.

Peirson, G, Brown, R, Easton, S, Howard, P and Pinder, S. (2006), Business Finance, 9th edn, McGrawHill, North Ryde, NSW.

Pettit, R. (1977), "Taxes, transaction costs and the clientele effect on dividends", Journal of Financial Economics, December 1977, pp.419-436.

Richardson, G., Sefcik, S. and Thompson, R. (1986), "A test of dividend irrelevance using volume reactions to a change in dividend policy", Journal of Financial Economics, December 1986, pp.313-333.

Rozeff, M. (1982), "Growth, beta and agency costs as determinants of dividend payout ratios", Journal of Financial Research, Fall 1982, pp.249-259.

Shuetrim, G., Lowe, P. and Morling, S. (1993). "The Determinants of Corporate Leverage: A Panel Data Analysis," RBA Research Discussion Papers rdp9313, Reserve Bank of Australia, Sydney.

Smith, C. and Watts, R. (1992), "The investment opportunity set and corporate financing, dividend and compensation policies”, Journal of Financial Economics, December 1992, pp.263-292.

Walker, S. and Partington, G. (1999), "The value of dividends: evidence from cum-dividend trading in the ex-dividend period", Accounting and Finance, 39(1999): 275-296.

\footnotetext{
${ }^{1}$ Forecast incremental capacity for generation has been sourced from AEMO, with overnight plant costs assumed to be $\$ 1500 / \mathrm{kW}$ for CCGT plant, $\$ 900 / \mathrm{KW}$ for OCGT, $\$ 2500 / \mathrm{kW}$ for wind, $\$ 3000 / \mathrm{kW}$ for Biomass, $\$ 3500 / \mathrm{kW}$ for Solar and $\$ 5000 / \mathrm{kW}$ for Geothermal. We use AER network capex from regulatory determinations and extend these on a straight line basis to 2015, then assume a $20 \%$ drop in capex between 2016-2020.

${ }^{2}$ Average residential energy consumption increased by about $16 \%$ over this period, from $6.4 \mathrm{MWh}$ to $7.4 \mathrm{MWh}$ pa (ESAA, 1994).

${ }^{3}$ The variables included some firms who; paid out more than $70 \%$ of earnings; paid out less than $40 \%$ of earnings; raised or did not raise external finance; firm scale; industry; earnings stability; liquidity; balance sheets structure and so on.

${ }^{4}$ See especially Lintner (1956, pp.98-101).

${ }^{5}$ This was found to be driven virtually entirely by the introduction of Capital Gains Tax in September 1985, the introduction of dividend imputation in July 1987 and the introduction of a 15\% tax on the earnings of Superannuation Funds in July 1988.

${ }^{6}$ At this point in time, the Australian Company Tax Rate was $36 \%$.

${ }^{7}$ Their argument draws intuitive logic from Lintner (1956) in that a firm will not make an announcement to raise dividends unless the Board of Directors truly expects that the increase in profit is a sustainable one - because by raising dividends, the Board has in effect committed to a continuous stream of dividends at that higher rate. And from an investors' viewpoint, an upgrade to the dividend payout rate might be thought of as providing some assurance to the market that there are no hidden adverse conditions facing the firm. Of course, this overlooks the various other means by which the firm can communicate its forward position to the market.

${ }^{8}$ Asquith and Mullins (1983) observed that firms making announcements on dividends for the first time or resuming after a ten-year period of no dividends tended to exceed market returns materially over a 2-day trading period. Healy and Palepu (1988) also found significant market reaction to changes in dividend policies; they found that firms who initiated dividends also experienced a significant increase in earnings the following year. Conversely, they found that when firms cancelled their dividends, this was also accompanied by a material decrease in the earnings for at least one year after the change in dividend policy.

${ }^{9}$ Source: IQ Capital

${ }^{10}$ IPPs in the US experienced sharp growth in the late 1990s fuelled by aggressive use of project finance. As Joskow (2006) and Finon (2008) noted, more than $230,000 \mathrm{MW}$ of power plant capacity was added to the US grid, most of which was project financed, almost of half of which resulted in financial distress. Those with active dividend programs are forecast to pay about $18.1 \%$ of free cash flows, with gearing of $46.7 \%$. Two years ago, the average debt level of this peer group was $60 \%$ and thus de-gearing and capital restructuring has been prominent. Above all, the classical taxation system in the US does not lend itself to aggressive dividend payout ratios; return of capital is more likely to arise from share repurchase programs, which is beyond the scope of our analysis.

${ }^{11}$ See Ofgem at http://www.ofgem.gov.uk/Media/PressRel/Documents1/RIIO\%20Oct\%20Press\%20notice.pdf

${ }_{12}^{12}$ For details see http://www.worldenergyoutlook.org/docs/weo2011/factsheets.pdf

${ }^{13}$ This will be especially important for Australian listed entities, since franked dividend-seeking retail investors now represent only $14 \%$ of ASX200 equity (down from 25\%), and simultaneously, the marginal investor, growth-seeking foreign institutions who cannot utilize franking credits, have risen to $41 \%$ of the ASX200.

${ }^{14}$ The issue here is that shareholders can create synthetic dividends by selling a proportion of their holdings.

${ }^{15}$ For those firms operating under an imputation system, an unexpected build-up in franking credits can be dealt with via special dividends and raising DRP discounts to facilitate an equivalent 'net dividend' position.
} 